\title{
The Production and Distribution of the Information Press
}

In the spring of 1782 the English writer Sarah Goudar spent her mornings in her apartment overlooking the Palais-Royal. Each day her maid set a table alongside the balcony for her, where a teakettle, teapot, teacup, sugar bowl, bread, butter, and the Parisian daily Journal de Paris were all arranged before her. For Goudar, reading the newspaper was part of a daily routine by which she learned of the "lettered world." One morning she spilled her tea on the paper and destroyed it, so she wrote to the editors to request a new copy. In her published missive to the editor requesting a new edition of the paper, she chronicled her reading habits, emphasizing the daily practice of reading in her home. ${ }^{1}$ Goudar painted an image of print consumption as a time of daily enjoyment, yet the place of the newspaper in the quotidian habits of Parisian and provincial consumers was a rather recent phenomenon.

The Journal de Paris, the Parisian Journal général de France, and the provincial newspapers published under the title Affiches, annonces, et avis divers were launched, for the most part, in the 1770 s, when they began to flourish throughout France. While similar newspapers had appeared as early as the 1750s, many of those papers had struggled to survive. Drawing on the historiography of the press and original archival research, this chapter traces the production, distribution, and consumption of the information press. To understand the newspapers that emerged in the 1770s and 1780s requires an examination of the relationship of newspapers to three Old Regime 
mediators: the network of censors who regulated the printing industry; the postal system through which editors delivered newspapers to subscribers; and the editors themselves. Such structures guided editorial decision-making and are thus essential to understanding the way that the information press presented content to and invited contributions from readers.

\section{Establishing the Affiches}

Before mid-century, newspapers circulated in urban centers, but readers outside Paris had little access to periodicals. The scant number of newspapers in the kingdom reflected the elaborate state system of assigning printing monopolies known as privileges to select publishers. In the seventeenth century the French government had given the exclusive rights to print newspapers to the Gazette de France, which consisted of short reports written by the ministry of foreign affairs, and provided readers with a sense of geopolitical news that favored king and church. The most prevalent publications in the countryside were reprints of the Gazette. The printer's privilège granted a title of possession and permission to publish on a renewable basis, in exchange for the submission of all published content to government censorship. In principle, the royal privilège allowed the printers of a periodical a monopoly to publish on specified subjects and protected editors from infringement by other publications.

By the eighteenth century, the monopolies on content were split between three newspapers: the Gazette de France, the Journal des sçavans, and the Mercure. ${ }^{2}$ The Gazette maintained a monopoly on all geopolitical news. All remaining subjects were the domain of the two other privileged publications: the Mercure, which published on literature, theater, and society and court gossip, and the Journal des sçavans, which concerned learned subjects in the sciences and medicine. While other newspapers and magazines did appear in the seventeenth and early eighteenth centuries, the system of privilèges stifled the domestic market, and many periodicals failed.

The history of the emergence of the affiches is more complex. In 1749, after four generations in the Renaudot family, the privilège to publish the Gazette was sold. Two years later, its new owners, the chevalier Denis Rabiot de Meslé and the financier Louis Dominique Le Bas de Courmont, launched a second paper titled Affiches de Province, which shared the advertising format of the Feuille du Bureau d'Adresse that Renaudot had published in the seventeenth century. The Affiches targeted provincial readers and printed on various domestic topics. By 1753 Rabiot de Meslé and Le Bas de Courmont devised a plan to expand their enterprise by printing similar papers in all the major cities of the kingdom. They envisioned a network of offices for editing 
and publishing each paper, called bureaux d'adresse, which they intended to set up in each city. ${ }^{3}$ Their goal was to sell the offices to provincial notables and to oversee the communication of news between the various bureaux. Ultimately, the plan was too ambitious, and Rabiot de Meslé and Le Bas de Courmont were unable to sell their vision to investors. ${ }^{4}$ Plagued by personal and familial debts, Rabiot de Meslé lost influence over the Gazette and the affiches he had launched; he died in 1763. In contrast, his business partner's fortunes increased; Le Bas de Courmont became a fermier général and continued to oversee ownership of the Gazette and the Affiches de Province. ${ }^{5}$

After 1756 Le Bas de Courmont adopted a new strategy — to grant the right to publish a newspaper in the style of his Affiches de Province to one person in each town in exchange for the payment of an annual fee. Aimé Delaroche, a bookseller-printer in Lyon, had already negotiated this kind of arrangement for his Affiches de Lyon in $1750 .{ }^{6}$ Soon papers titled Affiches, annonces, et avis divers, commonly known as affiches, began appearing in port cities such as Marseille, Nantes, and Bordeaux, and along the borderlands of the kingdom in Lille, Besançon, Metz, and Strasbourg. ${ }^{7}$ Over time, more affiches were launched throughout the interior. The affiches published on a wide range of general information subjects, including weather, legal proceedings, commercial news, literature, and fashion, which editors adjusted to suit local and regional interests. The price Le Bas de Courmont charged publishers for the exclusive rights to publish in a given town varied, but most paid between 100 and 200 livres for the privilège. By 1778 Courmont's total annual revenue from such license fees throughout the kingdom had reached 5,000 livres. ${ }^{8}$

Once Le Bas de Courmont began selling the rights to publish in provincial towns, the number of affiches published in France grew, but many of the early papers were unable to stay in business for more than a year. Historians of the press have described the decades between 1750 and 1770 as an initial phase, when printers experienced difficulty in finding a market and sustaining their publications. ${ }^{9}$ After 1770 their fortunes changed. The royal edict of June 1771 mandated that royal printers circulate published contracts of sale, and many printers seized on the opportunity to supplement their newspaper content with such listings. While affiches had certainly existed before, Gilles Feyel has argued that the edict of June 1771 gave them a newfound staying power. ${ }^{10}$ Newspapers founded after 1770 were much more likely to remain in business.

While the edict provided stability to affiches throughout the kingdom, the content of the papers diversified to reflect the interests of individual editors and the markets where the papers appeared. By 1775 approximately twenty more cities were publishing affiches, including Dijon, Grenoble, Avignon, Aix-en-Provence, Montpellier, Perpignan, Montauban, Limoges, Poitiers, La 
Rochelle, Tours, Amiens, Reims, Meaux, Sens, Auxerre, Le Mans, Angers, and Bayonne. ${ }^{11}$ Among the fifty largest towns in the kingdom, two-thirds now had their own newspapers. Most such towns were capitals of their généralités or seats of a cour souveraine. Another strong indicator of whether a paper would appear in a town was the presence of a chambre de commerce or a consulat marchand -70 percent of affiches had such a commercial institution. ${ }^{12}$ More than demography, literacy, or the presence of specific administrative institutions, an active market and the development of strong readership were the necessary factors for the success of the affiches. ${ }^{13}$

Meanwhile, the media landscape in Paris underwent its own transformation. In 1751 Le Bas de Courmont and Rabiot de Meslé had secured the rights to publish the Affiches de Paris. After Le Bas de Courmont died in 1777, the privilège for the Parisian paper was sold, and the paper reappeared under the title Annonces, Affiches et Avis Divers, ou Journal général de France. ${ }^{14}$ The Parisian affiches also faced a new competitor when the Journal de Paris began publication in 1777. Whereas the affiches were usually published on a weekly basis, the Journal de Paris was the first daily newspaper to appear in France. In page format and in content, it resembled the provincial and Parisian affiches.

By the 1780 s most major towns had a newspaper of their own, and the number of newspapers publishing in the interior had grown substantially. The généralités of Paris, Orléans, and Tours had three affiches each, while the généralités of Lille, Châlons, Dijon, Rennes, La Rochelle, Bordeaux, Montpellier, and Aix-en-Provence each had two papers. ${ }^{15}$ The density of newspapers was especially high in the north, the northeast, and the Parisian region. By the eve of the French Revolution, forty-four towns had their own newspapers, and the affiches became the main source for local and regional news.

\section{The Editors}

The editors of the provincial and Parisian affiches were usually prominent businessmen from regional centers who remained in the town to edit and oversee the publication of their newspapers. Most of them already held the position of imprimeur-libraire. As printer-booksellers, they were responsible for printing government decrees for local distribution. They also published books and pamphlets, and some owned bookshops where they sold the works they had printed. The affiches thus provided a useful vehicle for maximizing their profits in an enterprise for which they already possessed the technology and an experienced labor force. ${ }^{16}$

The editors who were not printer-booksellers came from a wide variety of backgrounds. Five were lawyers (avocats), one was a notary, one a procureur, and two others were professors. An apothecary and a master clockmaker 
were among the founders of the Journal de Paris. For a few years, a dentist ran the Affiches de Montpellier. At least two of the editors had some religious training. The editor of the Journal général de France, Louis Abel Bonafous, Abbé de Fontenay, was a Jesuit until the suppression of the Society of Jesus; Albert Brondex, the editor of the affiches in Metz, had received a Benedictine education, though he never entered the order. Nevertheless, more editors (twelve) described themselves as printers and booksellers than any other profession.

For at least five of the editors, running the newspaper took on a social and professional significance, which they indicated by taking on the title of journaliste. By the 1780s the people publishing newspapers had begun to think of themselves not merely as gazetiers, that is, as compositors and distributors of information, but rather as journalistes who exercised judgment over their content. While the self-description of journaliste originated in Holland, it grew in popularity in French literary papers in the 1720s and 1730s. Denis Diderot's entry in the Encyclopédie for "journaliste" transformed the meaning and accelerated the adoption of the term. ${ }^{17}$ In his estimation, a journaliste was responsible for publishing excerpts on literature, the sciences, and the arts, but also for helping the reader understand them-a journalist ought to instruct readers and exercise fairness in evaluating the information presented in the paper. Diderot's journaliste was also guided by two aims: the progress of humanity and the love of truth. ${ }^{18}$ The self-description of journaliste thus emphasized the creative, authorial role that working on the affiches entailed. This reformulation was further underscored by newspaper editors in the 1780 s who began changing their titles from affiches, annonces, et avis divers to instead include the word journal. These shifts in the self-presentation of editors and the names of their papers were emblematic of the changing ways that editors thought of their work.

Some of the editors were themselves affiliated with the same social circles as men of letters. Jean Milcent, the director of the affiches in Rouen, was a member of the société littéraire in Bayeux and the Académie des Palinods in Rouen. He was introduced in Marie Thérèse Rodet Geoffrin's salon by Jean le Rond d'Alembert and Diderot, and he wrote poetry. ${ }^{19}$ Louis Couret de Villeneuve, the editor of the Affiches de l'Orléanois, was the father-in-law of the prominent printer Charles-Joseph Panckoucke, who was known especially for publishing the Mercure de France. ${ }^{20}$ Panckoucke's sister, Amélie Suard, was a salonnière and writer; her husband was a journalist. René JouyneauDesloges in Poitiers and Jean-François Blouet in Metz were members of learned societies and academies. ${ }^{21}$ Some editors also revealed a particular interest in bienfaisance; the editors of the Journal de Lyon and Journal de Paris were especially active in founding and supporting philanthropic societies. ${ }^{22}$ 
Many editors expressed their interest in belles lettres, beneficence, and a desire to print useful content; such values were widely shared throughout the kingdom.

Among the editors and printers of the newspapers under study, women produced at least five. All identified themselves as widows, a status that by law and custom entitled them to run the family business as printer and bookseller. ${ }^{23}$ When the imprimeur-libraire André Giroud died in Grenoble, his wife, Justine Souverant, took over the family printing shop and bookstores. She founded and edited the affiches as a means of augmenting her business, and she successfully ran the paper until $1792 .{ }^{24}$ The publisher of the Affiches de Rennes, Jeanne Le Saulnier du Vauhello, took over her husband's print shop when he died in 1771; she ran it until $1823 .{ }^{25}$ Élisabeth Charlot, the widow of Louis Godart, printed the affiches in Amiens until 1777. ${ }^{26}$ For some of the women who produced affiches, very little is known except for the requisite references on the newspaper page. Identified only by her husband's surname; the widow Nicolas printed the Affiches d'Artois in Arras. ${ }^{27}$ The widow Barbe-Thérèse Lefebvre Marchand would take over the paper in 1789. Marguerite Pagès-Marinier, the editor of the Affiches de Montpellier, was a dentist who also ran a reading room (cabinet de lecture). Much of her story survives because of Pagès-Marinier's protracted legal battles with another printer in Montpellier and with Le Bas de Courmont over the right to publish the Affiches de Montpellier. Rather than paying for the privilège to print in Montpellier, she had instead secured local permissions from provincial authorities. It took ten years and the intervention of royal authorities for Courmont to wrest publishing rights from Pagès-Marinier. ${ }^{28}$

In general, the editors were men and women from middling backgrounds living in urban centers who were well educated and well established in their communities. In many cases they had inherited a print shop from their fathers and would eventually pass on the business to their children. Far from the Grub Street writers who penned nouvelles à la main in Paris, the editors of the affiches were local notables interested in preserving the revenues the affiches provided. ${ }^{29}$ The evolution of their newspapers after 1789 would reveal a range of ideologies from conservative monarchist to Jacobin, but such political outlooks were obscured before the Revolution. In their content analysis of the revolutionary press, Pierre Rétat and Claude Labrosse have argued that it was possible to determine the general political inclination of a newspaper's editors based on the content they chose to publish. ${ }^{30}$ Yet before the outbreak of the Revolution most editors eschewed overtly political content, and the political positions of the men and women who published affiches would be shaped 
by the very experience of the Revolution. As a result, this book does not trace a political genealogy of the editors.

\section{Finding an Audience}

Before beginning to print their newspapers, editors published a prospectus to explain the content they intended to cover. In it, editors identified their prospective audience, outlined general content areas, and invited their subscribers to participate in the affiches by sending letters to the paper. Editors played a key role in framing the content and circulation of the affiches, both by inviting contributions from readers on particular topics and in choosing which responses to print. The prospectuses of the affiches have received extensive treatment in histories of the press, beginning with Eugène Hatin's foundational study. ${ }^{31}$ Jack Censer has argued that the prospectuses of the affiches demonstrated the "overwhelming inclination" of the editors to recognize their publications' audiences. The prospectus served to communicate the editor's aims to two audiences: the officials who had to approve the paper and the readers who would eventually purchase a subscription. ${ }^{32}$

The newspapers the editors designed were short, four-page publications consisting of one piece of paper folded in half on the left-hand side. At the top of the first page, the title "Annonces, Affiches et Avis Divers" of the town or généralité appeared. ${ }^{33}$ Titles evolved as their prospective markets expanded or shrank; some papers even printed under different titles depending on the newspaper's destination. ${ }^{34}$ While some affiches, such as the papers published in Nantes and Chartres, featured an engraving depicting the town, most newspapers were very simple and displayed minimal ornamentation, as illustrations were costly. Each edition included the issue number, the title, and the date; the pages were typically numbered consecutively for the entire year. Most affiches appeared on a weekly basis, though the Journal de Paris appeared daily, and the Journal général de France published three times a week. The Journal de Paris also included meteorological and astronomical observations on the first page.

Below the front matter, the paper was printed in two columns. The first page featured the annonces: the lists of properties sold, as required by the 1771 edict, along with a series of advertisements featuring goods, land, and houses for sale. Families looking for a cook, domestic servant, or tutor often took out ads in the paper. ${ }^{35}$ Dentists, oculists, and itinerant craftsmen advertised their services to potential employers. Few manufactured goods were advertised, with the exception of books. ${ }^{36}$ The occasional notice of a lost dog appeared. Many editors inserted announcements from their subscribers free of charge as 
a way to generate more subscriptions. The affiches typically charged 12 sous to print an advertisement from nonsubscribers, though the cost varied by the length of copy and the newspaper in which it appeared. ${ }^{37} \mathrm{~A}$ newspaper's last page had a series of rubrics; announcements of theatrical spectacles, the price of goods, lottery results, and word puzzles were among the topics featured.

The remaining space on the front page and the two pages in the middle of the affiches were composed of an array of content that included news and all other information relevant to the "utilité générale," which varied from week to week: belles lettres, the sciences, the arts, geography and travel, history and the classics, agriculture, medicine, bienfaisance, jurisprudence, administration, obituaries for prominent figures, current events, and human-interest pieces. To date, Jack Censer and Gilles Feyel have done the most comprehensive content analysis of the affiches. ${ }^{38}$ They estimate that after publishing the advertisements from subscribers and the announcements required by state and local officials, editors had control of approximately two-thirds of the content of the paper, which they filled with an assortment of topics that touched on daily life, including administrative announcements, current events, anecdotal stories, book and theater reviews, agricultural and scientific observations, and medical remedies. Among this content, there was also "a rich body of letters from readers, who intervened often on the major issues of the moment." ${ }^{39}$ Historians of the Old Regime press have noted the robust presence of letters to the editor in the affiches, but no one has systematically analyzed who wrote the letters and what the letters had to say. Published letters to the editor speak to an entirely new realm of eighteenth-century lives and social activity. They are especially important because historians have shown that private correspondence serves as a powerful touchstone of social, cultural, and political life in the eighteenth century.

In general, letters from readers under the heading "A l'Auteur du Journal" or "Au Rédacteur du Journal" followed a similar structure. They opened with an address to the editor and often included the date and location of their composition..$^{40}$ The body of the letters varied in content, depending on the subject matter and aims of the writer. The writers of the letters ended with a closing such as "yours, etc.," and they then commonly specified their name. ${ }^{41}$ As chapter 2 explores in depth, in some cases writers indicated their social position or profession. Other writers did not want their name published in the paper, although they might well offer a pseudonym, or their initials, or sign simply as "a subscriber."

In the 1770 s the letters to the editor became a regular feature of the information press. Letters varied in length from a paragraph to several pages. The amount of space dedicated to letters varied from newspaper to newspaper. 
The affiches in Lyon, Marseille, and Angers, for example, published letters only on an occasional basis. In Paris, Poitiers, Dijon, and Metz, by contrast, published letters became a regular component of the newspapers' content. The total number of letters published in a given newspaper reflected editorial choices. Some editors seemed to design their publications from the outset with correspondence in mind, even printing regular appeals for letters from their readers. In their prospectus, some editors included a call for letters from readers that explained the newspaper's aims and contents to potential readers, and they even indicated the topics of correspondence they would like to receive. The strategies for publishing letters from readers also varied. Some editors collected a set of letters on a particular theme or question, which they published together in one issue. Others published letters as they were received in a more serialized fashion. But inevitably the space devoted to letters had to be balanced with other content that was also considered essential, such as advertisements and administrative reports.

The rate of publication of letters to the editor grew over time. While they first appeared in a few affiches as early as the 1760 s, their sustained publication took off in the provinces only after 1770 , as the number published rose from an occasional letter to more than a hundred per year. After 1782 the number of letters published in the provincial press more than doubled, a volume of correspondence that was sustained through 1789. In Paris the aggregate number of letters published increased even more dramatically, from fewer than ten a year before the Journal de Paris to more than three hundred letters a year after it began publication in 1777. In contrast to the weekly publication cycle of most provincial affiches, the Journal de Paris had four pages to fill every day, and letters quickly became a key component of the periodical. As more newspapers were launched in the 1780s, the letters became a fixture through the beginning of the Revolution. Nearly seven thousand letters appeared in the affiches between 1770 and the end of 1788 . The growth in the publication of letters over the last two decades of the Old Regime corresponded to the process by which editors honed their abilities to foster discussion and curate correspondence with their readers.

The editorial style of journalism in such newspapers did not yet resemble that of the nineteenth and twentieth centuries. Rather, theirs was a journalism "de type épistolaire," through which the editor made a call for contributions from his or her readers. ${ }^{42}$ Such epistolary journalism relied heavily on the contributions of readers and subscribers. After all, editors depended on the intellectual and social circles in their town and in provincial society more broadly to buy the newspaper. Affiches flourished where they were able to engage their readers in ongoing conversations and debates. 
Editors structured their papers in ways that made room for dialogue by posing questions to readers, inviting responses from subscribers, and printing various observations and debates that juxtaposed competing points of view. In doing so, they conveyed the notion that the newspaper was in conversation with its readership. ${ }^{43}$ In some cases, the editor left a brief note $d u$ rédacteur at the end of a letter to the editor to offer more context or assure readers that a response was forthcoming. The editors of the Journal général de France, Affiches des Trois-Évêchés et Lorraine, and the Affiches de Toulouse all indicated in such notes that they would provide comments on a subscriber's letter in the next number of their newspapers. ${ }^{44}$ In Poitiers, Michel-Vincent Chevrier offered to print the excerpts from the Mercure that a letter writer referenced..$^{45}$ The editor of the Affiches de Rennes included her own lively responses to the letters she printed; on one occasion she checked the math in a letter she published. ${ }^{46}$ Editors also used notes to make their decision-making process more transparent to their readers, by explaining why the paper had chosen to print or not print a particular piece they had received. For example, the editor of the Affiches de la Basse-Normandie invited a letter writer to contribute more letters and explained that the correspondence would be printed serially because of its length. ${ }^{47}$ Such editorial interaction no doubt shaped the kinds of letters that the papers received from their subscribers. They also helped encourage the flourishing of letters to the editor in the affiches, which continued to grow over the two decades preceding the Revolution.

Moreover, editors shared and reprinted content from similar publications. Editors routinely cut information from other periodicals and used that content to fill the pages of their own newspapers. The practice of the "scissors editor," where editors cut content from other newspapers and reprinted it in their own, often without attribution at all, persisted in this period throughout the Atlantic world. ${ }^{48}$ The men and women who published affiches likely also reprinted content without acknowledging the content's origin, but in at least 440 of the letters published between 1770 and 1788 (approximately 6.4 percent of the total corpus), the editors indicated that they had reprinted the letter from another newspaper. For example, Justine Giroud indicated some of the letters in her Affiches du Dauphiné were "au Rédacteur des Affiches de Metz" or "Aux Auteurs du Journal de Paris." ${ }^{49}$ The periodicals on which the editors drew were mixed. They republished content from other affiches in Paris and the provinces, from specialized journals, and from other periodicals from the surrounding region.

Figure 1.1 presents a network visualization that traces the information flows from their source to the newspaper that reprinted them. A network plot is a way of visualizing a set of relationships through a depiction of nodes 
and ties. Each node represents an individual, in this case one newspaper. Each tie (or edge) indicates one connection between two individuals. In this figure, each tie represents one case of republication, where an editor cut a letter to the editor from another newspaper and pasted it into the paper she or he produced. To distinguish the original source of publication from the affiches where the letter was republished, the arrow points away from the newspaper where the letter originally appeared and toward the paper that republished it. A density of ties between two particular newspapers indicates that such papers republished content with greater frequency. The more central a particular newspaper within the figure, the more often it was cited by several of the surrounding newspapers. In contrast, the nodes on the periphery of the visualization with a single tie were republished in only one case, by only one newspaper. This network figure is particularly useful for identifying the relationships between papers, gauging the significance of a particular newspaper for other affiches, and identifying the other types of periodicals to which editors turned for content. Significantly, letters to the editor appeared not only in the information press but also in learned journals and other censored and uncensored periodicals.

The Parisian newspapers were a popular and frequent source from which provincial editors took information. The centrality of the Parisian publications (nodes 11 and 12) shows that most of the provincial affiches drew content from their Parisian counterparts. The ties between the affiches show that editors republished the most letters from Parisian newspapers, but the Parisian papers were not the exclusive sources of information. The clustering of provincial affiches near the center of the network (nodes 2, 7, $8,9,10$, and 13) shows that provincial affiches also shared content among themselves. Some of the republished content was regionally oriented. For example, the Affiches d'Aix (node 1) reprinted content from the Journal de Provence in Marseille (8). In the southwest where newspapers were scarcer, the Affiches de Bordeaux (18) reprinted letters from the Affiches de Montpellier (19). Literacy rates, density of newspapers, and regional connections and interests mattered.

Moving toward the periphery of the network, the ties become less dense, and specialized journals (indicated as triangles) and regional newspapers (represented as circles) become more prominent. In many cases, such publications were linked to provincial affiches by just one letter (that is, one tie). The surrounding circular and triangular nodes suggest that the markets for each newspaper had particularities to which the editor was attentive, and editors published content according to the interests of their particular readership. For example, the Affiches de l'Orléanois (node 10) published content from nearby 


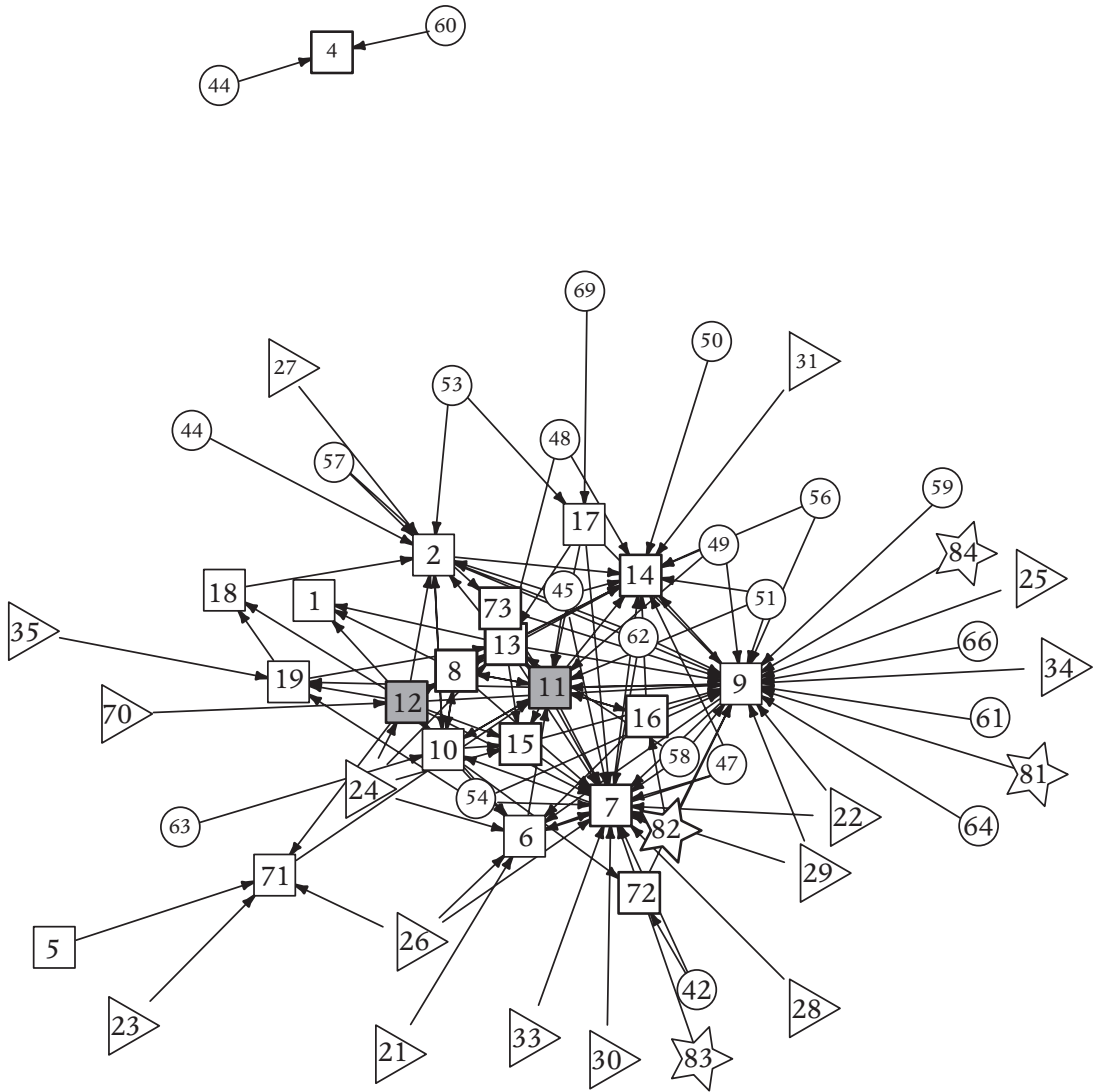

FIgURE 1.1 Reprinted content in the affiches, 1770-1788.

Each node represents a newspaper, and each tie indicates one letter an editor republished after its initial appearance. The shapes indicate types of newspapers as follows:

Squares: all the provincial newspapers under study in this book, including the affiches published in Angers (2), Grenoble (7), Marseille (8), Metz (9), Orléans (10), Poitiers (13), and Troyes (15).

Squares shaded gray: the Parisian newspapers, the Journal de Paris (node 12), and the Journal général de France (node 11).

The remaining shapes indicate other periodicals from which the Parisian and provincial affiches drew content:

Stars: newspapers published abroad.

Triangles: specialized journals on the arts, sciences, health, or literature.

Circles: general information newspapers not consulted in this study.

The unique identifier number in each node indicates a particular newspaper. All newspapers are listed in full by their unique identifier in appendix $A$.

Angers (2) and from Paris (11 and 12), but also from provincial newspapers further afield such as the affiches in Marseille (8) and Verdun (63), as well as the Morning Herald from London (82). The Affiches de Toulouse (14) republished content from the Parisian Journal général de France (11), but also from the specialized periodical the Journal militaire (31), from newspapers in the southwest, 
such as the Affiches de La Rochelle (50), and from northern and central France, such as the Feuille de Flandres in Lille (49), the Affiches de Normandie in Rouen (16), and the Affiches de Moulins (56). The network visualization of reprinted letters shows that the affiches shared content with one another and with other periodicals in France and abroad. Together they formed a circuit to share practical information from one newspaper to another.

\section{Censorship}

The content of the affiches was influenced not only by the editor but also by a complex system of censorship at the local and national levels. In principle, the system of royal privilèges set the limits for what could appear in print in France. Privilèges delineated the subject matter of each publication, but they also enforced material quality control by indicating, for example, the kind of paper that the printer had to use and the aesthetic quality of the type setting. ${ }^{50}$ They also required that the editor designate who was authorized to print the publication; the specified publisher then had to register with the guild of booksellers and printers. This requirement protected the interests of master craftsmen and distinguished authorized publications from counterfeit and clandestine copies. Alongside this system of licensed publication, a burgeoning clandestine book trade and the circulation of newspapers published abroad for a French audience also existed. ${ }^{51}$ Finally, publications required an approbation, a formal sanction delivered by royal censors that stated they had reviewed and approved content.

For the affiches in particular, the process began with securing the necessary license to print from the propriétaire du privilège, Louis Dominique Le Bas de Courmont (and later his successor, Pierre Benezech). Since the privilège for all affiches technically originated in the privilège granted to the Gazette, the royal ministry officially in charge of censoring the affiches was the secretary of foreign affairs. In the case of the Gazette, the secretary of foreign affairs had the oversight to censor information concerning geopolitical affairs that impinged on the way the monarchy was perceived. Once the necessary provincial and royal authorities approved the prospectus, the editor printed their paper on a weekly basis and sent copies to both their fellow editors who published affiches in other French towns and the royal censor in the Department of Foreign Affairs who gave "directives, compliments, and reprimands," based on the content. ${ }^{52}$

Traces of the changes that censors required of the editors of affiches are rare, though a few records exist. Colin Jones has emphasized the petty nature of the changes that censors required in his evaluation of the editor's 
proofs of the Affiches de Province before and after censorship. Beyond the Affiches de Province, there is little evidence that the censor in Foreign Affairs exercised any role in suppressing other affiches' content. The affiches generally covered topics that were more local and practical in nature, and in doing so they steered their content away from topics that might run afoul of the censors. The affiches rarely experienced suspensions or printed formal retractions, though there were exceptions. The intendant suspended the Affiches des Trois-Évêchés et Lorraine in April 1782; the paper resumed publication in July. The editors of the Affiches de la Haute Normandie in Rouen and the Affiches de Nantes received reprimands for their content and adjusted their future editions accordingly. ${ }^{53}$ In Toulouse the publisher Jean-Florent Baour faced two lawsuits in which powerful local legal officials argued that he had exposed private matters in his Affiches. Despite winning both cases, the cost of defending himself was too much; he gave up his privilège to the paper in $1776 . .^{54}$

The Journal de Paris experienced greater scrutiny. Vergennes, the minister of foreign affairs, together with the support of Jean-Charles Lenoir, the lieutenant general of the Paris Prefecture of Police, surveilled the daily. ${ }^{55}$ Between June 4 and 27, 1785, they suspended the Journal de Paris for printing a poem that ridiculed Princess Maria Christina of Saxony, a relative of MarieAntoinette. For their part, the owners of the Journal insisted they had printed the verses by pure ignorance; they had no intention to offend the royal family, whom they said they counted among their subscribers. ${ }^{56}$ In December 1786 the censor assigned to the Journal was reprimanded for allowing an éloge to the comte de Guibert to appear in the paper. ${ }^{57}$ There is little archival evidence to suggest that provincial newspapers received the same level of scrutiny as the Journal de Paris, and some editors tested the political and philosophical waters. The criticism of royal policies and institutions published in the Affiches de Bordeaux, for example, further illustrates the laxity of censorship for some of the affiches. ${ }^{58}$

The records of the editors publishing affiches from the 1750s through the 1780 s reveal that maintaining the rights to publish and determining which parties must approve newspaper content was complex and often confusing for the printers. Most newspapers, after all, were censored not by the Department of Foreign Affairs but rather by the chancellerie, which also oversaw the French book trade..$^{59}$ Where archival records of the affiches survive, they concern three key questions: disputes between rival printers in the same town over who had the right to publish the newspaper; confusion over which local and royal institutions had the right to designate the editor; or inquiries regarding who had the right to censor a particular paper. ${ }^{60}$ 
In practice, the system of censorship was made more complex because of the potential impact of the powerful head of the royal chancellerie, provincial networks of patronage, and local politics more generally. By the 1760s Guillaume-Chrétien de Lamoignon de Malesherbes, the director of the royal publishing office, had successfully challenged the sole authority of the secretaries of state to censor the affiches, so editors needed not only a license from Le Bas de Courmont but also the approval of the chancellerie, who assigned censors to read the paper. Once the central administration had reviewed a request for the rights to publish, they would contact local authorities to request their approval before they permitted the printer to move forward with publication. The decision went to the intendant of the province, then to a local magistrate in the town, and in some cases to the lieutenant general of police. In urban centers under the jurisdiction of a parlement, the court also had to authorize the publication. If all of the provincial authorities granted approval, the editor would then produce a prospectus that described the paper he or she intended to publish, which was posted around the town for consultation. Editors who met the expectations at each step were then awarded the exclusive right to publish the affiches in the town. ${ }^{61}$

In addition to this lengthy approval process, according to their licensing agreement, each edition of the paper was supposed to be read by a local censor. In practice, the authority that held this responsibility varied from town to town, as evidenced in the particular approbations at the end of each issue of the newspaper that testified that the content of the paper had been seen by the appropriate authority. These notices usually took the form "with approval," "read and approved," or "seen and approved," and they were followed by the visa of the lieutenant general of police or the general notice "permission to print and distribute." 62 Since the chancellerie did not name censors systematically, some affiches were submitted only to the local lieutenant general of police; his approval sufficed to indicate that the content of the paper was not offensive to the royal person. However, in other locations the parlements also assumed an active role in regulating the content of the paper; magistrats and procureurs $d u$ roi could and sometimes did denounce the contents of the paper. ${ }^{63}$

Other affiches had specifically designated royal censors. In Orléans the Abbé de Reyrac, the rector and curé of Saint-Maclou and a friend of Condillac, censored the affiches. In Caen the royal censor assigned to the affiches was Le Paulmier, the rector of the Univérsité de Caen, a member of the local academy, and a subdelegate to the intendant. ${ }^{64}$ The regulation of censorship and assignment of censors to the affiches generally aligns with the processes Malesherbes described in his correspondence as chief censor from 1750 to 
1763: censorship was a negotiated process that encompassed a great deal of collaboration between authors and censors. Censors saw themselves as men of letters who were enhancing literary quality. Their correspondence centered on discussions of tone and style - that is, on the quality of books-as much as content. Publications that received an approbation had to express the right ideas about the king and the church, but they also had to be written in good prose. ${ }^{65}$

In short, the manner in which an individual royal censor carried out his work varied. In some instances, censors did not read the copy they were assigned to police, and the printer moved forward with publication, thus implicitly allowing indiscreet content to slip into print. Alternatively, Malesherbes sometimes tacitly responded to publishers' requests for leniency by directing the censor in charge of the particular publication to show greater forbearance in their evaluation of the content. Thus, while the system of censorship for newspaper editors in the 1770 s and 1780 s was extensive, the ostensibly stringent guidelines on the content of the domestic press were rather unevenly enforced, generating a climate of tolerance between editors and censors. ${ }^{66}$

For writers from the 1750s until the end of the Old Regime, censorship was a process of collaboration between state censors, publishers, and authors. While the royal administration maintained a commitment to censorship, correspondence between censors shows a complex process of negotiation, which was intended to serve not only the interests of the state but also those of guilds and of well-established men of letters. After all, authors and censors often came from the same social circles, and many censors were themselves authors. What is more, censorship was often a secondary occupation: most censors were members of the clergy, lawyers, doctors, and professors; some were state administrators. Working as a censor was not particularly profitable in and of itself, but it did impart a sense of prestige and the possibility of acquiring a wealthy patron or a more lucrative appointment. ${ }^{67}$ As such, most censors took their work seriously, even assuming the role of copyeditor, correcting spelling and arithmetic, and revising poor grammar. They worked closely with authors, so much so that the director of the book trade often asked editors of a particular book which censor they would prefer to work with. Censors routinely negotiated content with the authors whose work they reviewed. ${ }^{68}$ The extent of collaboration is further underscored by the low percentage—only about 10 percent—of books refused publication. ${ }^{69}$

The structure of royal censorship is particularly salient for the study of the affiches because it underscores how much one's social networks and financial resources shaped one's ability to publish a book. For most literate 
men and women, the path to publishing a book was beyond their means and social connections, and it necessarily relied on patronage, financial resources, and knowledge of the intricacies of the royal bureaucracy. But publishing a letter to the editor of a newspaper was significantly more attainable.

\section{The Distribution of the Affiches}

Once the editors had navigated the necessary licensing and censorship barriers, they mailed the newspaper to their subscribers via the royal post. Ensuring that the affiches had an audience required editors to get the publication to their readers quickly and consistently. The royal post, which was authorized to deliver all letters and newspapers, made such circulation possible. The press and the post had long been intertwined, for the earliest "news papers" in Europe were published by the postmasters themselves. ${ }^{70}$ In the late eighteenth century, subscribers to newspapers, including the affiches, still received their newspapers in the mail.

Paris was firmly situated at the center of the postal distribution network. Parisians could post correspondence to the provinces from seventy-eight mailboxes found in shops and bakeries around the capital, or they could mail the letter from the general post office on the rue Platrière. ${ }^{71}$ The postal roads that connected major cities and towns throughout the kingdom emanated from Paris like spokes on a wheel, dotted with relay stations. The statesponsored postal system had since the fifteenth century required relay riders to travel via these "post roads." Over the eighteenth century this exchange network had grown ever more connected, nearly doubling the number of relay stations where travelers and mail couriers could find a place to rest, a fresh horse, and news. By 1788 a total of 1,426 relay stations stood along the king's roads. By 1792 twelve of the fifteen postal roads from Paris had daily mail departures. ${ }^{72}$

In the late eighteenth century, the fifteen main postal routes were served by coaches that carried mail and newspapers along set routes, with a network of secondary roads reaching the more remote interior of the kingdom. This system of roads enabled timely communication in the north and in the towns surrounding Paris. Correspondence from Paris arrived in Rouen within one or two days, whereas postal delivery to Bordeaux took five to six days, and delivery to Lyon required six days. In general, mail from Paris arrived within eight days to sixty-four major towns and cities in France. ${ }^{73}$

Sending a letter from one provincial town to another typically took longer and incurred an additional fee, as letters were routed along the major highways through the hub of Paris. For example, a letter sent from Paris 
to provincial centers such as Lyon or Bordeaux would reach such distant destinations more rapidly than a centrally located town such as ClermontFerrand that was not on a main postal road. Even given these constraints, figures from the early 1790 s suggest that one could receive information by post from anywhere in the kingdom within a twenty-day time frame, depending on the sender's and the recipient's proximities to major postal routes. ${ }^{74}$ The time frame between the printing of a newspaper and its arrival to the subscriber in part explains the tendency for the affiches to print useful information, rather than particularly timely stories. Moreover, while such conveyance may appear slow by twenty-first-century standards, Jay Caplan has argued that the prevalence of idioms from this period such as "post-haste" in English, en poste in French ("with haste, at full speed"), or con la celerità de la stapheta in Italian ("as fast as a mounted courier") underscore that for preindustrial Europeans the post moved at a pace that was quite swift indeed. ${ }^{75}$

Securing enough subscribers was critical to the financial viability of the affiches, and postage costs were a considerable concern for editors and subscribers. After mid-century, two innovations reduced the financial risk of producing a newspaper and encouraged more subscribers: lower postage costs and a new subscription model. First, lower postage costs strengthened the economic viability of starting and sustaining a newspaper. The cost of mailing newspapers via the royal post decreased in $1763 .{ }^{76}$ While the royal post continued to convey newspapers and letters from town to town, by the 1760s intra-urban exchanges known as petites postes emerged, first in Paris and then in provincial centers, including Bordeaux, Rouen, Lyon, Nancy, and Marseille. The petites postes had two key advantages: they were much quicker than the royal post, with pickups as often as nine times a day in Paris, for example; and they were much less expensive than the royal post. Moreover, they allowed the sender to prepay for a letter, thus relieving the financial burden on the recipient. Up until this point, the recipient of a letter typically paid the postage on its arrival, and the rate paid varied depending on the type of letter or package sent and the distance it traveled. ${ }^{77}$ The custom persisted until the 1840 s, when postage stamps were first issued. The system of citywide postal delivery made possible by petites postes was faster and less costly, though mail still occasionally reached the wrong recipient or was lost altogether. House numbering was just beginning in the late eighteenth century. ${ }^{78}$

Second, newspaper producers began to include the fee for transport (known as "franco" or "franche de port") in the cost of the subscription, which they collected in advance of delivery. Editors advertised the cost of a subscription, along with instructions about how and where to subscribe in their prospectus and in notices in the newspaper throughout the year. 
The price of an annual subscription to the weekly affiches published in Angers, Bordeaux, Caen, Dijon, Grenoble, Lyon, Montpellier, Orléans, Reims, Toulouse, and Troyes was six livres for those who lived in town. In Aix-en-Provence, Amiens, Compiègne, Metz, Poitiers, and Rennes, annual subscriptions to residents in town were between seven and eight livres. ${ }^{79}$ The affiches published in Rouen and Arras were the most expensive, with annual subscriptions of twelve livres in town. All affiches also advertised subscription prices for delivery throughout the kingdom, which included the cost of postage. The price for such subscriptions was typically 7 livres, 10 sous for those papers that charged 6 livres in town, and 9 livres for those that charged 7 livres in town, but the papers in Rouen and Arras charged 15 and 13 livres, respectively.

The cost of a subscription to the affiches was relatively inexpensive in comparison to other periodicals. Annual subscriptions for the affiches cost approximately half of what subscribers paid for a year of the Journal des dames, and a fifth the price of a subscription to the Mercure de France. In 1777, when the Journal de Paris began publishing on a daily schedule, the cost for an annual subscription was 24 livres in Paris itself, and 31 livres, 4 sous for the provinces. Most editors advertised their office address along with a series of addresses of notaries and lawyers in nearby towns so that potential readers in the region could pay for subscriptions locally. The affiches in Arras, for example, allowed subscriptions with nine notables in the region, including a bookseller in Douai and one in Lille, a notary in Béthune and another in Lillers, the directors of the post in Hesdin and Dunkerque, a customs officer in Péronne, a goldsmith in Aire, and a cloth manufacturer in Saint-Omer. ${ }^{80}$ The editor of the Affiches de Reims even circulated preaddressed envelopes so that his subscribers in nearby Troyes could more easily subscribe to his paper with the local notary, Jean-François Delion. ${ }^{81}$ The publishers of the Affiches d'Aix used similar prefilled forms as receipts for subscriptions. ${ }^{82}$ Taken together, the subscription model and lower postage costs reduced the risk to newspaper owners and increased access for subscribers. Whereas the early affiches in the 1750s had often failed, most of the newspapers launched in the $1770 \mathrm{~s}$ stayed in print well into the Revolution.

\section{Estimating the Readership}

Precisely how many copies of the affiches circulated through the post remains unknown, since complete subscription logs or print runs no longer exist that would indicate the total number of newspapers printed and sold. Lacking complete records, historians of the press have combined the claims 
made by printers and partial subscriber lists to estimate total circulation for most affiches between 200 and 750 subscribers, although some affiches had more than 1,000. From such estimates, historians of the press have extrapolated a total number of subscriptions to the approximately forty affiches as somewhere between 8,000 and $30,000 .^{83}$

Yet total readership was invariably higher than the total number of subscribers. In Reims the editor of the affiches estimated the readership for the paper was at least four times the total number of subscribers, while the editor of the Affiches de Provence claimed each copy of his newspaper reached twenty or thirty people. ${ }^{84}$ Moreover, by mid-century, individuals did not have to subscribe to a paper in order to read it because they had access to a range of reading rooms and local lending libraries. Urban French readers could pay to read the international gazettes and various other newspapers in cabinets de lecture, privately owned reading rooms that allowed members to read a variety of publications on the premises-and sometimes to rent items to take home. Often run by booksellers, such reading rooms provided access to new literary works and major periodicals at an economical price..$^{85}$ In the case of the Journal de Provence in Marseille, the publisher himself ran a reading room where the entire run of the paper was offered free of charge. The greater flexibility in the fees charged and the pay schedules in cabinets meant that a more diverse public could read the publications offered there. ${ }^{86}$

Still other readers joined sociétés de lecture, which were associations of literary enthusiasts who pooled their resources to buy copies of one or more publications; the members of such literary cooperatives established time frames during which members could take a book or periodical home before passing it on to the next cosubscriber. Chambres de lecture also existed, as book clubs, where individuals gathered in one space to read and debate the papers they purchased collectively. Since the 1750 s the number of such venues had increased rapidly. Nantes, for example, had six, with a readership of about a hundred people in each collective. By the end of the Old Regime, most provincial towns in France had at least one, and these reading rooms remained active long after the Revolution. ${ }^{87}$ Their members tended to be minor members of the nobility and doctors, lawyers, and businessmen. Occasional newspaper advertisements written by the editors publicized local reading rooms and listed the publications available and the cost of dues for access to the collections.$^{88}$ One particularly evocative description of a reading room was written by a member of a chambre in Niort in 1775, where "minds are enlightened by communication, hearts are united by approaching one another, taste for society is purified, confidence and concord maintained." In the reading room, readers met to pose questions, propose problems, and 
develop hypotheses; in short, those in attendance could "find enlightenment and advice" in a space that was "suitable to sociability, to the common interest." 89

For those living in urban locations, reading rooms provided an economical alternative to a private subscription. Furthermore, a range of other spaces including cafés and clubs made newspapers available to their customers for free. ${ }^{90}$ Such spaces provided access to print, were well lit and heated, and offered an opportunity for readers to discuss publications with one another. Café reading was social, and it fostered public opinion through discussion and criticism of periodicals. ${ }^{91}$ Moreover, the prevalence of newspapers in such spaces suggests not only that the total readership of a given newspaper was higher than the total circulation but also that reading and discussing collectively were common practices.

The practice of sharing print and reading collectively persisted not only among the middling classes and members of the liberal professions but also among the popular classes. According to notarial records, most domestic workers in Paris knew how to read by the latter half of the eighteenth century, and they had access to reading material in the households where they worked. They attended public readings that took place in cafés and gambling rooms, which were often elaborations on information contained in newspapers. There were also public readings on the streets of Paris. Daniel Roche has argued that the only portion of the press inaccessible to the popular classes was likely the literary periodicals, which assumed a formal education. ${ }^{92}$

In the provinces, literate villagers read newspapers aloud to their neighbors. The oral transmission of news was shared in places of work, especially the blacksmith's shop, the market and fountains, and the benches that typically lined the place publique, as well as inns and drinking establishments. ${ }^{93}$ Provincial chateaus had libraries, the very existence of which created the possibility for people to borrow or take print matter. Inns also offered readers in the countryside access to periodicals. Some fifty postmasters subscribed to the Mercure. And many itinerant individuals that traversed the countryside brought print with them: stewards, agents, butlers, servants, and occasionally coachmen brought books and new ideas to the countryside..$^{94}$ In the winter months, peasants gathered in a barn or private house for a veillée d'hiver to share folklore and news; while predominantly a space for the transmission of local oral tradition, there were occasions when a literate intermediary read aloud to the group. ${ }^{95}$ Letters published by country noblemen in La Feuille Villageoise early in the Revolution recounted the way they gathered together with "their" peasants in the evening to read the paper together. After the Revolution had begun, one writer referred to the experience of reading the 
newspaper aloud as a "civic catechism" through which the minds and the souls of the farmers who gathered were enlightened. ${ }^{96}$ Much less is known about what the peasants themselves thought of the messages conveyed in such publications. Nevertheless, news circulated widely, even in rural settings.

Taking into account all of the spaces where people congregated to read and discuss news, and the spaces where newspapers were available-from libraries and reading rooms to cafés and workshops - the total audience of the affiches went well beyond the number of newspapers published. Jeremy Popkin has argued that the Gazette de Leyde with a subscriber list of four thousand likely found its way into the hands of 50,000 to 100,000 readers. A similar extrapolation suggests that the provincial and Parisian affiches may have had 130,000 to 200,000 readers, and perhaps more. ${ }^{97}$ Indeed, the readers of the affiches made up a significant portion — and likely the majority—of the French newspaper-reading public.

Since the 1770s the affiches had only grown in popularity. By the eve of the Revolution, they were key sources of local and national information for the French reading public. Invariably, the content of the newspapers was mediated by the editors who produced them, the censors who policed them, and the postal system that distributed them. Nevertheless, the editors designed their papers to give their readers the sense that they were participating in a dialogue. Editors crafted prospectuses that advertised the paper to invite such participation. As chapter 2 will show, editors printed letters from their readers, and they responded to their subscribers' contributions with editorial notes. Such letters to the editor became a critical component of the information press.

Writing a letter to the editor afforded the opportunity for men and women to see their ideas in print. Publishing a book or a pamphlet required economic means, a professional network, and a certain know-how. Such thresholds restricted the group of people who would become authors. By comparison, the costs of writing a letter to the editor were low. In the format of a public letter, those eager to share their ideas found in the affiches a comparatively smooth path to publication. 